2013

\title{
The Geography of Financial Literacy
}

\section{Christopher Bumcrot}

Applied Research \& Consulting LLC, chris.bumcrot@fgsglobal.com

Judy Lin

Applied Research \& Consulting LLC, judy.lin@fgsglobal.com

Annamaria Lusardi

George Washington University School of Business, alusardi@gwu.edu

Follow this and additional works at: https://digitalcommons.usf.edu/numeracy

Part of the Social and Behavioral Sciences Commons

\section{Recommended Citation}

Bumcrot, Christopher, Judy Lin, and Annamaria Lusardi. "The Geography of Financial Literacy." Numeracy 6, Iss. 2 (2013): Article 2. DOI: http://dx.doi.org/10.5038/1936-4660.6.2.2 


\title{
The Geography of Financial Literacy
}

\begin{abstract}
This paper explores how well equipped today's households are to make complex financial decisions in the face of often high-cost and high-risk financial instruments. Specifically we focus on financial literacy. Most importantly, we describe the geography of financial literacy, i.e., how financial literacy is distributed across the fifty US states. We describe the correlation of financial literacy and some important aggregate variables, such as state-level poverty rates. Finally, we examine the extent to which differences in financial literacy can be explained by states' demographic and economic characteristics. To assess financial literacy, five questions were added to the 2009 National Financial Capability Study, covering fundamental concepts of economics and finance encountered in everyday life: simple calculations about interest rates and inflation, the workings of risk diversification, the relationship between bond prices and interest rates, and the relationship between interest payments and maturity in mortgages. We constructed an index of financial literacy based on the number of correct answers provided by each respondent to the five financial literacy questions. The financial literacy index reveals wide variation in financial literacy across states. Much of the variation is attributable to differences in the demographic makeup of the states; however, a handful of states have either higher or lower levels of financial literacy than is explained by demographics alone. Also, there is a significant correlation between the financial literacy of a state and that state's poverty level. The findings indicate directions for policy makers and practitioners interested in targeting areas where financial literacy is low.
\end{abstract}

\section{Keywords}

financial literacy, financial capability

Creative Commons License

\section{(;) (8)}

This work is licensed under a Creative Commons Attribution-Noncommercial 4.0 License

\section{Cover Page Footnote}

Christopher Bumcrot, one of the founders of Applied Research \& Consulting LLC (ARC), is a strategic consultant and researcher focused on the financial services, technology, communications, and B2B sectors. Chris was a founder of Loan Pricing Corporation, a financial software and database publishing firm that tracks pricing in the primary and secondary corporate lending markets. Chris has a BA in applied mathematics from Yale University.

Judy T. Lin is a Director at Applied Research \& Consulting LLC (ARC) where she oversees the company's quantitative research practice. Judy has a background in both social and clinical psychology from the graduate program at New York University, with a specialization in attitude formation and attitude change. She has a BA in psychology from Yale University.

Annamaria Lusardi is the Denit Trust Distinguished Scholar and Professor of Economics and Accountancy at the George Washington School of Business and Director of the Global Financial Literacy Excellence Center. Previously, she was the Joel Z. and Susan Hyatt Professor of Economics at Dartmouth College. She has also taught at Princeton University, the University of Chicago Public Policy School, the University of Chicago Booth School of Business, and Columbia Business School. In 2008 she was a visiting scholar at Harvard Business School. She is the recipient of the William E. Odom Visionary Leadership Award from the Jump\$tart Coalition for Personal Financial Literacy and the National Numeracy Network's inaugural 2012 Steen Award.

This theme collection: financial literacy is available in Numeracy: https://digitalcommons.usf.edu/numeracy/vol6/ iss2/art2 


\section{Introduction}

Over the past thirty years, individuals have had to become increasingly responsible for their own financial security following retirement. The shift from defined benefit (DB) to defined contribution (DC) plans has meant that workers today have to decide both how much they need to save for retirement and how to allocate pension wealth. Furthermore, financial instruments have become increasingly complex and individuals are presented with new and ever-more-sophisticated financial products.

How people borrow money and manage their liabilities has also undergone major changes. Prior to the recent financial crisis, consumer credit had expanded rapidly, as had mortgage borrowing. Consumers who borrow via credit cards or subprime mortgages were in the historically unusual position of being in charge of deciding how much they can afford to borrow. Alternative financial services, such as payday lending, have grown rapidly in the states where they are allowed to operate. $^{1}$

This paper explores how well equipped today's households are to make complex financial decisions, as they are often faced with high-cost and high-risk financial instruments. Specifically we focus on financial literacy, by which we mean the knowledge of a few fundamental financial concepts. Most important, we describe the geography of financial literacy, i.e., how financial literacy is distributed across the fifty US states. We also describe the correlation of financial literacy and some important aggregate variables, such as poverty rates at the state level. Finally, we examine how much differences in financial literacy across states can be explained by demographic and economic characteristics.

The paper highlights two main findings. First, financial literacy is rather low in the population, and most Americans are not familiar with fundamental concepts that should form a basis for financial decision making. Given the current shift toward more individual responsibility for financial well-being, this is a worrisome finding. Second, there is considerable geographic variation in financial literacy, something that only a few studies are beginning to document. As discussed in this paper, some of these differences are due to demographic and economic characteristics across states, but these variables cannot explain all of these differences. One direction for future research is to better understand the origins of these geographical differences in financial literacy.

\footnotetext{
${ }^{1}$ See Skiba and Tobacman (2009).
} 


\section{Measuring Financial Literacy}

Economic models of consumer financial decision making require agents to be very knowledgeable. For example, the standard theoretical framework used to model consumption/saving decisions posits that consumers save during periods of high earnings to provide for the decline in income after retirement. Even in relatively simple formulations of the model, the consumer must do a good job of predicting potential future labor earnings, pension benefits, Social Security benefits, interest rates, inflation rates, mortality risk, and health shocks - to name just a few important components. And optimal behavior also requires, at minimum, that calculations be made with an understanding of compound interest and the time value of money.

To assess knowledge of fundamental concepts that are essential for financial decision making, five questions were added to the 2009 National Financial Capability Study (NFCS) to measure financial literacy. Because the survey covers respondents across each US state, it is possible to examine not only how financially literate Americans are but also how financial literacy varies geographically. Descriptions of the study and the financial literacy questions are provided below.

\section{The National Financial Capability Study}

The 2009 NFCS consists of three linked surveys: (1) the National Survey-a nationally projectable telephone survey of 1,488 American adults; (2) the State-byState Survey - an online survey of approximately 28,000 American adults (roughly 500 per state, plus the District of Columbia); and (3) the Military Survey-an online survey of 800 military service members and spouses. This paper is based on data from the State-by-State survey, administered to respondents between June and October 2009. ${ }^{2}$ Data collection and design of the survey instruments were supported by the Financial Industry Regulatory Authority (FINRA) Investor Education Foundation. ${ }^{3}$

The overarching research objectives of the NFCS were to benchmark key indicators of financial capability and evaluate how these indicators vary with underlying demographic, behavioral, attitudinal, and financial literacy characteristics. Financial capability cannot be judged simply by looking at one indicator. Rather, it covers several aspects of behavior. Consistent with the surveys that have been done in other countries, these behavioral aspects include how people manage their resources, how they make financial decisions, the skill set they

\footnotetext{
2 See Appendix A for details on the weighting used in this report.

${ }^{3}$ More information about this survey is provided at: www.finrafoundation.org/programs/capability/index.htm and www.usfinancialcapability.org. See also Lusardi (2011).
} 
use in making such decisions, and the search and information elaboration that goes into those decisions.

It is worth noting that a handful of other countries have so far collected data on financial literacy/financial capability. The United Kingdom was among the first to design a survey on financial capability, in 2005, and similar initiatives have been undertaken in New Zealand, Australia, Ireland, Canada, and the Netherlands. New Zealand is one of the few countries to have followed up with a second survey, designed to assess the changes in financial knowledge and behavior of New Zealanders over a three-year span.

The NFCS survey data provide a rich set of information on four main areas of Americans' financial capability: (1) making ends meet, (2) planning ahead, (3) managing financial products, and (4) financial literacy and financial decision making. This paper focuses on one specific area: financial literacy, as will be explained in more detail below.

\section{Financial Literacy Questions}

To evaluate financial knowledge, respondents were asked five questions covering fundamental concepts of economics and finance encountered in everyday life. The questions assessed ability to make simple calculations about interest rates and inflation as well as understanding of the workings of risk diversification, the relationship between bond prices and interest rates, and the relationship between interest payments and maturity in mortgages. The wording of the questions and answer choices follow (correct answers are indicated with two asterisks):

Suppose you had $\$ 100$ in a savings account and the interest rate was $2 \%$ per year. After 5 years, how much do you think you would have in the account if you left the money to grow?

More than $\$ 102 * *$

Exactly $\$ 102$

Less than $\$ 102$

Don't know

Prefer not to say

Imagine that the interest rate on your savings account was $1 \%$ per year and inflation was $2 \%$ per year. After 1 year, how much would you be able to buy with the money in this account?

More than today

Exactly the same

Less than today **

Don't know

Prefer not to say 
True or false: Buying a single company's stock usually provides a safer return than a stock mutual fund.

True

False **

Don't know

Prefer not to say

If interest rates rise, what will typically happen to bond prices?

They will rise

They will fall **

They will stay the same

There is no relationship between bond prices and interest

rates

Don't know

Prefer not to say

True or false: A 15-year mortgage typically requires higher monthly payments than a 30-year mortgage, but the total interest paid over the life of the loan will be less.

True $* *$

False

Don't know

Prefer not to say

The first question measures numeracy, or the capacity to do a simple calculation related to compounding of interest rates. Of course complex interest compounding is also important, but the focus here is on whether individuals get the general idea of calculations relating to interest rates. The second question measures understanding of inflation, again in the context of a simple financial decision. The third question gauges knowledge of risk diversification; it is a joint test of knowledge about stocks and stock mutual funds and of risk diversification, since the answer to this question depends on knowing what a stock is and that a mutual fund is composed of many stocks. As employees are increasingly asked to select their pension investment portfolios, it is important to ask questions related to risk diversification. ${ }^{4}$ The fourth question is about the relationship between the price and yield of a fixed-income asset; it is the most complex question of the set and is designed to differentiate among levels of financial knowledge. Finally, the fifth question measures the understanding of mortgages and mortgage payments, an important question given the recent US experience with subprime mortgages.

\footnotetext{
${ }^{4}$ When the Enron Corporation filed for bankruptcy in 2001, it turned out that a large number of employees had invested their entire pension assets into the company stock. It is of interest to assess whether employees have learned from that event.
} 
The multiple-choice answer format was used to make it easier for people to simply select their preferred response. Moreover, respondents could indicate they did not know the answer or could choose to refuse to answer. This procedure prevented respondents from choosing at random, and it also enables researchers to differentiate across different levels of financial knowledge.

The first three questions were fielded in a special module on financial literacy that was added to the 2004 Health and Retirement Study (HRS), a sample of over 1,200 respondents age 50 and over (Lusardi and Mitchell 2011b). The questions were further added to wave 11 of the 2007-08 National Longitudinal Survey of Youth covering respondents age 23-28 (Lusardi et al. 2010) and, in 2008, to a module in the RAND American Life Panel (ALP), an Internet-based panel data set (Lusardi and Mitchell 2009). Subsequently the questions have been fielded in Germany, the Netherlands, Italy, Sweden, Russia, Japan, and New Zealand (Lusardi and Mitchell 2011c), and this issue of Numeracy features new analysis of financial literacy data based on these questions from Switzerland (Brown and Graf 2013), France (Arrondel et al. 2013), Romania (Beckmann 2013), and Australia (Agnew et al. 2013). Moreover, the questions have been added to surveys in developing countries. Financial literacy questions similar to the ones used in the NFCS have been used in Mexico and Chile (Hastings and Tejeda-Ashton 2008; Hastings and Mitchell 2011; Behrman et al. 2012), and similar results have been reported in India and Indonesia (Cole et al. 2011). The question about bond pricing was first tested in a survey module fielded among Dutch households (Van Rooij et al. 2011) and later added to the ALP (Lusardi and Mitchell 2009), and it has been shown to be very effective in differentiating between financially sophisticated and unsophisticated respondents. Across the board, these variables have been found to do a good job of characterizing peoples' levels of financial knowledge.

\section{Financial Literacy among the Population}

The responses to the five questions are reported in Table 1 . While the correct response to certain individual questions is relatively high, there are still sizeable proportions of incorrect and "don't know" answers to those questions. For example, while the interest rate question was answered correctly by $78 \%$ of respondents, one in five Americans either got this simple calculation wrong or did not know the answer. As described in Lusardi (2012), the level of numeracy is not high in the US population, and similar findings are reported in other countries as well. Similarly, one in three Americans could not provide the correct answer to the question about inflation (14\% were incorrect, and 19\% did not know), another rather basic question. The bond pricing question had the smallest proportion of correct answers - only 28\%. Both the bond pricing question and the risk question were difficult for respondents to answer, with nearly two out of five respondents stating they did not know the answer to each of these questions. The proportion of 
"don’t know" answers is highest for the risk diversification question. Seventy-six percent of respondents knew about the workings of mortgages.

Table 1

Response to Financial Literacy Questions

\begin{tabular}{lccc}
\hline & Correct & Incorrect & Don't know \\
\cline { 2 - 4 } Interest rate question & $78 \%$ & $10 \%$ & $10 \%$ \\
Inflation question & $65 \%$ & $14 \%$ & $19 \%$ \\
Risk diversification question & $53 \%$ & $6 \%$ & $40 \%$ \\
Bond price question & $28 \%$ & $33 \%$ & $37 \%$ \\
Mortgage question & $76 \%$ & $9 \%$ & $15 \%$ \\
\hline
\end{tabular}

Note: These figures do not sum to 100 because of rounding and because of refusal to answer the questions by some respondents.

When considering all of the questions together (Table 2, below), we find that slightly more than half of the population is able to correctly answer both the interest rate and inflation questions, and just under two-fifths can correctly answer these two questions plus the risk question. This is consistent with the findings documented in a variety of other studies using the same questions, both in the United States and in other countries (Lusardi and Mitchell 2009, 2011b, 2011d). Only $15 \%$ of respondents are able to answer all of the questions correctly. These findings show not only Americans' lack of financial literacy, but also their relative ignorance about fairly basic economic and financial concepts.

Table 2

Proportion of Correct Answers across Questions

\begin{tabular}{ccc}
\hline $\begin{array}{c}\text { Interest rate and inflation } \\
\text { questions correct }\end{array}$ & $\begin{array}{c}\text { Interest rate, inflation, and } \\
\text { risk questions correct }\end{array}$ & $\begin{array}{c}\text { All five questions } \\
\text { correct }\end{array}$ \\
\hline $57 \%$ & $39 \%$ & $15 \%$ \\
\hline
\end{tabular}

\section{Financial Literacy among Demographic Groups}

To examine how financial literacy varies across specific groups, a simple financial literacy index was constructed based on the number of correct answers provided by each respondent to the five financial literacy questions. An individual answering all five of the questions correctly has a financial literacy index of 5. An individual answering none of the five questions correctly has a financial literacy index of $0 .^{5}$ These index values allow researchers to calculate mean financial literacy scores for various subpopulations (e.g., demographic and geographic groups) and compare

\footnotetext{
${ }^{5}$ This is a rather simple index that does not take into account the degree of difficulty of each question. However, our analysis here is purely descriptive and aims to highlight some empirical facts.
} 
them to each other. The mean value of the financial literacy index for the United States as a whole is 2.99 .

Low levels of financial literacy are widespread in the population, but the problem is particularly severe among certain demographic groups. As shown in Figure 1 below, financial literacy is low among women, those with low educational attainment, and African-Americans and Hispanics, as also reported in previous work (Lusardi and Mitchell 2007, 2009, 2011a; Lusardi et al. 2010; Lusardi and Tufano 2009a, 2009b).

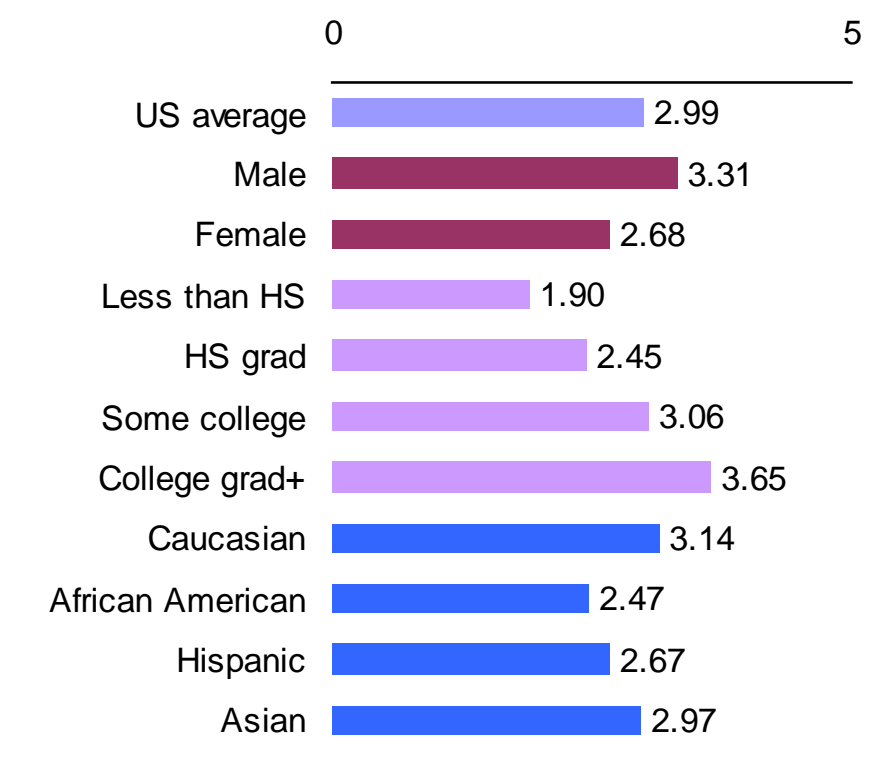

Figure 1. Financial literacy index by gender, education, and ethnicity.

\section{The Geography of Financial Literacy}

The financial literacy index allows us to examine the geographic distribution of financial literacy across the fifty US states (and the District of Columbia). The mean financial literacy index values range from 2.75 in Louisiana to 3.30 in New Hampshire. Figure 2 shows the states divided into quintiles based on their mean financial literacy index values. ${ }^{6}$ The states with the highest levels of financial literacy tend to be located across the northern half of the country, while the states with the lowest levels of financial literacy are in the eastern and southern parts of the country. Table 3 shows the financial literacy index values for the five states with the highest means and the five states with the lowest means. These simple

\footnotetext{
${ }^{6}$ A full list of financial literacy index scores for every state is provided in Appendix B.
} 
findings can be useful for policy makers and practitioners interested in targeting the areas where financial illiteracy is more prevalent.

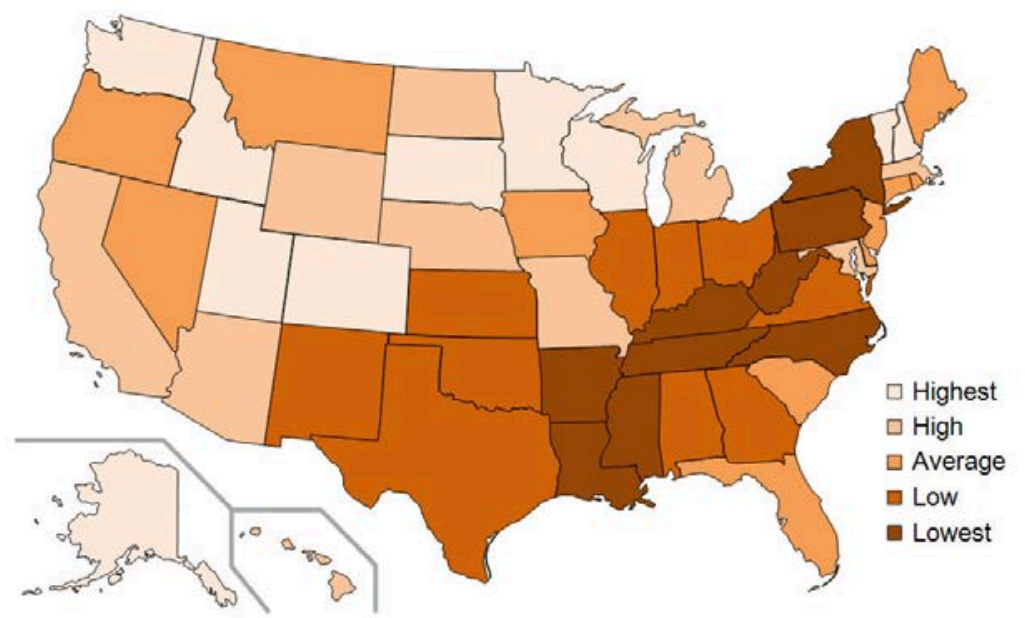

Figure 2. Financial literacy index by state.

Table 3

States with Highest and Lowest Financial Literacy

\begin{tabular}{|c|c|c|c|c|c|}
\hline Rank & State & $\begin{array}{l}\text { Financial Literacy } \\
\text { Index Score }\end{array}$ & Rank & State & $\begin{array}{l}\text { Financial Literacy } \\
\text { Index Score }\end{array}$ \\
\hline 1 & New Hampshire & 3.30 & 51 & Louisiana & 2.75 \\
\hline 2 & Minnesota & 3.28 & 50 & West Virginia & 2.83 \\
\hline 3 & South Dakota & 3.27 & 49 & Kentucky & 2.84 \\
\hline 4 & Idaho & 3.19 & 48 & Arkansas & 2.85 \\
\hline \multirow[t]{2}{*}{5} & Vermont & 3.17 & 47 & Tennessee & 2.86 \\
\hline & US Average & 2.99 & & US Average & 2.99 \\
\hline
\end{tabular}

Other studies have documented geographic differences in financial literacy. For example, Fornero and Monticone (2011) shows that financial literacy varies widely among Italian regions. While there is a distinct north-south divide in terms of financial literacy - with southern regions showing much lower levels of financial knowledge than the northern regions - there are also sharp differences in financial literacy among the regions in the north of Italy. Klapper and Panos (2011) also documented large geographic differences in financial literacy in Russia. According to their work, these differences are particularly pronounced in rural versus urban areas. This is consistent with the evidence provided in other papers that in the absence of formal education, people acquire financial literacy via interactions with others, for example peers (Duflo and Saez 2003, 2004; Van Rooij et al. 2011), and this is more likely in areas with high population density, such as urban areas. 


\section{Financial Literacy and Measures of Economic Distress}

To understand how financial literacy correlates with measures of economic distress at the state level, the following five measures were considered:

1) Poverty: Percentage of the state population below poverty level (data from the US Census Bureau American Community Surveys, 2008 and 2009).

2) Foreclosures: State foreclosure rates (data from CNN/Realty Trac, April 2009).

3) Unemployment: State unemployment rates (data from CNN/US Bureau of Labor Statistics, April 2009).

4) Bankruptcy: State bankruptcy rates (data from the American Bankruptcy Institute, 2009).

5) Public assistance: Percentage of state population receiving public assistance (data from the US Census Bureau American Community Surveys, 2008 and 2009).

While aggregate indicators, these measures summarize how well or poorly US states are doing in economic terms. A strong negative correlation $(r=-0.63$, $p<.001$ ) was found between the mean financial literacy index score for a state and that state's poverty level. As illustrated in Figure 3, states with higher financial literacy scores tend to have lower poverty levels and vice versa. ${ }^{7}$ No statistically significant correlations were found between financial literacy and the other four variables tested.

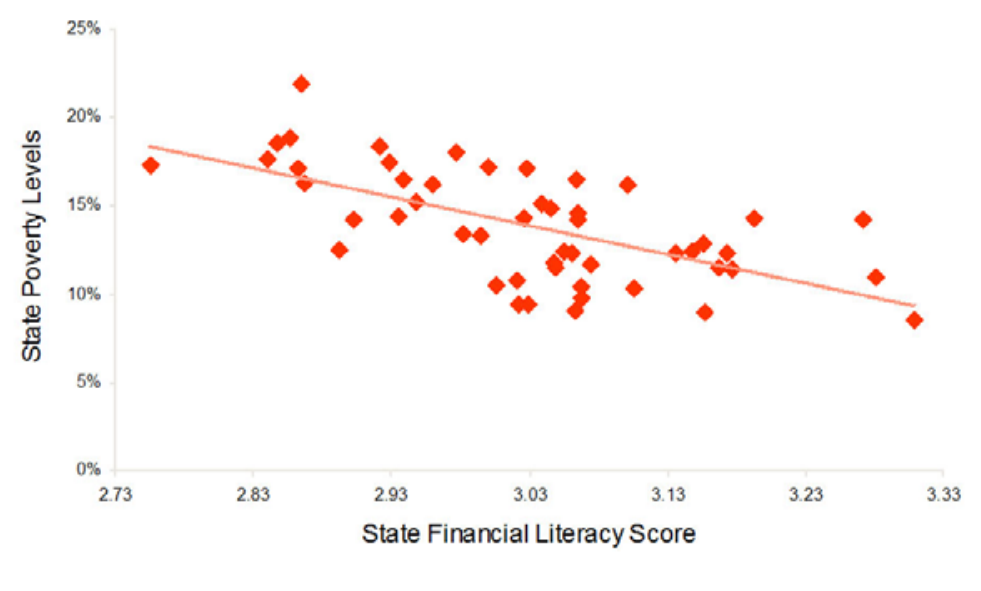

Figure 3. Financial literacy and poverty levels.

\footnotetext{
${ }^{7}$ A full list of financial literacy index scores and poverty levels for every state is provided in Appendix B.
} 


\section{Demographic Determinants of Geographic Variation in Financial Literacy}

To understand the degree to which geographic variations in financial literacy are attributable to variations in the demographic characteristics of the states, a hierarchical regression model was constructed in which demographic variablesage, gender, ethnicity, income, education, marital status - were entered in the first block, and state was entered in the second block. Dummy variables ${ }^{8}$ were created for gender, ethnicity, education, marital status, and state of residence; age and income were recoded into continuous variables. ${ }^{9}$

As Table 4 shows, demographic variables account for a sizeable share of the variation in financial literacy among respondents (20\%). The inclusion of state variables in the second block contributes very little additional predictive power $(0.4 \%)$. This finding suggests that if state-level public policies or practices have an effect on financial literacy, it may be that such effects are indirect, resulting from higher or lower levels of education and/or income in that state.

\begin{tabular}{lccc} 
Table 4 & & & \\
Components of Variation in Financial Literacy & & \\
\hline Variables entered & $\begin{array}{c}\text { Change } \\
\boldsymbol{R}^{2}\end{array}$ & $\boldsymbol{F}$ & $\boldsymbol{p}$ \\
\hline Demographic & .203 & 796.87 & $<.001$ \\
Geographic & .004 & 2.92 & $<.001$ \\
\hline
\end{tabular}

However, in a handful of states, a significant effect of geography was found. For example, South Dakota has a higher financial literacy index value than would be expected based on demographic characteristics (including education and income) alone. In contrast, Pennsylvania, New York, New Jersey, Connecticut, West Virginia, Kentucky, and Louisiana have lower financial literacy index values than would be expected based on demographic characteristics.

\section{Discussion and Concluding Remarks}

This paper highlights two main findings. First, financial literacy is rather low in the population, and most Americans are not familiar with fundamental concepts that should form a basis for financial decision making. Second, there is considerable geographic variation in financial literacy, something that only a few studies are

\footnotetext{
${ }^{8}$ In empirical economics, binary (or indicator or categorical) variables are typically referred to as dummy variables. These variables take the value of zero or one to indicate the absence or presence of some categorical effect.

${ }^{9}$ Additional details and statistics for the variables used in the regression model are provided in Appendix C.
} 
beginning to document. As discussed in the paper, some of these differences are due to demographic and economic characteristics across states, but these variables cannot explain all of the differences.

These findings provide suggestions for policy makers and practitioners interested in targeting the areas where financial illiteracy is more pervasive. For example, administrators of state college systems in areas of low financial literacy could leverage the data for implementing and funding financial education efforts. Moreover, the NFCS can serve as a good baseline against which to measure the effects of financial education programs at the state level. One direction for future research is to better understand the origins of the geographical differences in financial literacy.

\section{Acknowledgments}

The research reported herein was performed pursuant to a grant from the US Social Security Administration (SSA) funded as part of the Financial Literacy Research Consortium. The authors would like to thank three anonymous referees for suggestions and Olivia Mitchell, Christine Kieffer, and John Gannon for comments. The opinions and conclusions expressed herein are solely those of the authors and do not represent the opinions or policy of SSA, any agency of the Federal Government, or any other institution with which the authors are affiliated. (C)2013 Bumcrot, Lin, and Lusardi. All rights reserved.

\section{References}

Agnew, J., H. Bateman, and S. Thorp. 2013. Financial literacy and retirement planning in Australia. Numeracy 6(2). http://dx.doi.org/10.5038/19364660.6.2.7

Arrondel, L., M. Debbich, and F. Savignac. 2013. Financial literacy and financial planning in France. Numeracy 6(2). http://dx.doi.org/10.5038/1936$\underline{4660.6 .2 .8}$

Beckmann, E. 2013 Financial literacy and household savings in Romania. Numeracy 6(2). http://dx.doi.org/10.5038/1936-4660.6.2.9

Behrman, J., O. S. Mitchell, C. Soo, and D. Bravo. 2012. How financial literacy affects household wealth accumulation. American Economic Review 102(3): 300-304. http://dx.doi.org/10.1257/aer.102.3.300

Brown, M., R. Graf. 2013. Financial literacy and retirement planning in Switzerland. Numeracy 6(2). http://dx.doi.org/10.5038/1936-4660.6.2.6

Cole, S., T. Sampson, and B. Zia. 2011. Prices or knowledge? What drives demand for financial services in emerging markets? Journal of Finance 66(6): 1933-1967. http://dx.doi.org/10.1111/j.1540-6261.2011.01696.x 
Duflo, E., and E. Saez. 2003. The role of information and social interactions in retirement plan decisions: Evidence from a randomized experiment. Quarterly Journal of Economics 118: 815-842. http://dx.doi.org/10.1162/00335530360698432

- 2004. Implications of pension plan features, information, and social interactions for retirement saving decisions. In Pension design and structure: New lessons from behavioral finance, ed. O. S. Mitchell and S. Utkus, 137153. Oxford, UK: Oxford University Press. http://dx.doi.org/10.1093/0199273391.003.0008

Fornero, E. and C. Monticone. 2011. Financial literacy and pension plan participation in Italy. Journal of Pension Economics and Finance 10(4): 547564. http://dx.doi.org/10.1017/S1474747211000473

Hastings, J., and L. Tejeda-Ashton. 2008. Financial literacy, information, and demand elasticity: Survey and experimental evidence from Mexico. NBER Working Paper No. 14538. National Bureau of Economic Research, Cambridge, MA.

Hastings, J., and O. S. Mitchell. 2011. How financial literacy and impatience shape retirement wealth and investment behaviors. NBER Working Paper No. 16740. National Bureau of Economic Research, Cambridge, MA.

Klapper, L., and G. Panos. 2011. Financial literacy and retirement planning: The Russian case. Journal of Pension Economics and Finance 10(4): 599-618. http://dx.doi.org/10.1017/S1474747211000503

Lusardi, A. 2011. Americans' financial capability. NBER Working Paper No. 17103. National Bureau of Economic Research, Cambridge, MA.

2. 2012. Numeracy, financial literacy, and financial decision-making. Numeracy, 5(1). http://dx.doi.org/10.5038/1936-4660.5.1.2

Lusardi, A. and O. S. Mitchell. 2007. Baby boomers' retirement security: The role of planning, financial literacy and housing wealth. Journal of Monetary Economics 54: 205-224. http://dx.doi.org/10.1016/j.jmoneco.2006.12.001

- 2009. How ordinary consumers make complex economic decisions: Financial literacy and retirement readiness. NBER Working Paper No. 15350. National Bureau of Economic Research, Cambridge, MA.

— 2011a. The outlook for financial literacy. In Financial literacy: Implications for retirement security and the financial marketplace, ed. O. S. Mitchell and A. Lusardi, 1-13 Oxford, UK: Oxford University Press.

_ 2011b. Financial literacy and planning: Implications for retirement wellbeing. In Financial literacy: Implications for retirement security and the financial marketplace ed. O. S. Mitchell and A. Lusardi, 17-39. Oxford, UK: Oxford University Press.

http://dx.doi.org/10.1093/acprof:oso/9780199696819.003.0002 
. 2011c. Financial literacy around the world: An overview. Journal of Pension Economics and Finance 10(4): 497-508. http://dx.doi.org/10.1017/S1474747211000448

. 2011d. Financial literacy and retirement planning in the United States. Journal of Pension Economics and Finance 10(4): 509-525. http://dx.doi.org/10.1017/S147474721100045X

Lusardi, A., O. S. Mitchell, and V. Curto. 2010. Financial literacy among the young. Journal of Consumer Affairs 44(2): 358-380. http://dx.doi.org/10.1111/j.1745-6606.2010.01173.x

Lusardi, A., and P. Tufano. 2009a. Debt literacy, financial experiences, and overindebtedness. NBER Working Paper No. 14808. National Bureau of Economic Research, Cambridge, MA.

- 2009b. Teach workers about the peril of debt. Harvard Business Review November: 22-24.

Skiba, P. M., and J. Tobacman. 2009. Do payday loans cause bankruptcy? Vanderbilt Law and Economics Research Paper No. 11-13.

Van Rooij, M., A. Lusardi, and R. Alessie. 2011. Financial literacy and stock market participation. Journal of Financial Economics 101(2): 449-472. http://dx.doi.org/10.1016/j.jfineco.2011.03.006 


\section{Appendix A: Weighting}

Results from the National Financial Capability Study are weighted to be representative of Census distributions, based on data from the American Community Survey. National figures are weighted to be representative of the national population in terms of age, gender, ethnicity, education and Census Division. State figures are weighted to be representative of each state in terms of age, gender, ethnicity and education.

\section{Appendix B: \\ Financial Literacy Index Scores and Poverty Levels by State}

\begin{tabular}{|c|c|c|c|c|c|c|c|}
\hline \multirow[b]{2}{*}{ State } & \multicolumn{2}{|c|}{$\begin{array}{c}\text { Financial } \\
\text { Literacy Index }\end{array}$} & \multirow{2}{*}{$\begin{array}{c}\text { State } \\
\text { Poverty } \\
\text { Level* }\end{array}$} & \multirow[b]{2}{*}{ State } & \multicolumn{2}{|c|}{$\begin{array}{c}\text { Financial } \\
\text { Literacy Index }\end{array}$} & \multirow{2}{*}{$\begin{array}{c}\text { State } \\
\text { Poverty } \\
\text { Level* }\end{array}$} \\
\hline & $\begin{array}{l}\text { Index } \\
\text { Score }\end{array}$ & $\begin{array}{l}\text { Quin- } \\
\text { tile }\end{array}$ & & & $\begin{array}{l}\text { Index } \\
\text { Score }\end{array}$ & $\begin{array}{l}\text { Quin- } \\
\text { tile }\end{array}$ & \\
\hline New Hampshire & 3.304 & 5 & $9 \%$ & South Carolina & 3.023 & 3 & $17 \%$ \\
\hline Minnesota & 3.276 & 5 & $11 \%$ & Oregon & 3.021 & 3 & $14 \%$ \\
\hline South Dakota & 3.267 & 5 & $14 \%$ & New Jersey & 3.017 & 3 & $9 \%$ \\
\hline Idaho & 3.188 & 5 & $14 \%$ & Delaware & 3.016 & 3 & $11 \%$ \\
\hline Vermont & 3.172 & 5 & $11 \%$ & Virginia & 3.001 & 2 & $11 \%$ \\
\hline Washington & 3.168 & 5 & $12 \%$ & Texas & 2.995 & 2 & $17 \%$ \\
\hline Utah & 3.163 & 5 & $12 \%$ & Illinois & 2.990 & 2 & $13 \%$ \\
\hline Alaska & 3.152 & 5 & $9 \%$ & Kansas & 2.977 & 2 & $13 \%$ \\
\hline Colorado & 3.151 & 5 & $13 \%$ & New Mexico & 2.972 & 2 & $18 \%$ \\
\hline Wisconsin & 3.143 & 5 & $12 \%$ & Oklahoma & 2.955 & 2 & $16 \%$ \\
\hline Nebraska & 3.131 & 4 & $12 \%$ & Ohio & 2.943 & 2 & $15 \%$ \\
\hline Massachusetts & 3.100 & 4 & $10 \%$ & Georgia & 2.934 & 2 & $17 \%$ \\
\hline Michigan & 3.097 & 4 & $16 \%$ & Indiana & 2.930 & 2 & $14 \%$ \\
\hline North Dakota & 3.069 & 4 & $12 \%$ & Alabama & 2.924 & 2 & $18 \%$ \\
\hline Hawaii & 3.063 & 4 & $10 \%$ & District of Columbia & 2.917 & 1 & $18 \%$ \\
\hline Wyoming & 3.062 & 4 & $10 \%$ & New York & 2.898 & 1 & $14 \%$ \\
\hline Missouri & 3.061 & 4 & $15 \%$ & Pennsylvania & 2.887 & 1 & $13 \%$ \\
\hline California & 3.061 & 4 & $14 \%$ & North Carolina & 2.862 & 1 & $16 \%$ \\
\hline Arizona & 3.059 & 4 & $17 \%$ & Mississippi & 2.860 & 1 & $22 \%$ \\
\hline Maryland & 3.059 & 4 & $9 \%$ & Tennessee & 2.858 & 1 & $17 \%$ \\
\hline Maine & 3.056 & 3 & $12 \%$ & Arkansas & 2.852 & 1 & $19 \%$ \\
\hline Nevada & 3.050 & 3 & $12 \%$ & Kentucky & 2.843 & 1 & $19 \%$ \\
\hline Rhode Island & 3.044 & 3 & $12 \%$ & West Virginia & 2.835 & 1 & $18 \%$ \\
\hline Iowa & 3.043 & 3 & $12 \%$ & Louisiana & 2.750 & 1 & $17 \%$ \\
\hline Florida & 3.040 & 3 & $15 \%$ & & & & \\
\hline Montana & 3.033 & 3 & $15 \%$ & & & & \\
\hline Connecticut & 3.025 & 3 & $9 \%$ & & & & \\
\hline
\end{tabular}

*State poverty data are from the US Census Bureau American Community Surveys, 2008 and 2009. 


\section{Appendix C: Variables Used in Regression Analysis}

The following dummy variables were used in the analysis: gender $(1=$ male, $0=$ female), ethnicity (white, African-American, Hispanic, Asian, and other, with white as the omitted term), education $(1=$ college grad or more, $0=$ some college or less), marital status $(1=$ married/partnered, $0=$ not married/partnered $)$, state of residence (with Montana, which has the median financial literacy index score, as the omitted term). Age ranges were recoded into a continuous variable using the lower bound of each range $(18=18-24,25=25-29$, and so on in five-year increments up to $65=65$ or older). Income ranges were recoded into a continuous variable using the upper bound of each range (e.g., 15,000 = less than $\$ 15 \mathrm{~K}$; $150,000=\$ 100 \mathrm{~K}-\$ 150 \mathrm{~K})$; those with $\$ 150 \mathrm{~K}$ or more income were assigned a value of 200,000 .

The table below shows estimates for unstandardized coefficients and standard errors for each variable in the model.

(continued on next page) 
Numeracy, Vol. 6 [2013], Iss. 2, Art. 2

Table C1

Numeracy, Vol. 6 [2013], Iss. 2, Art. 2

\begin{tabular}{|c|c|c|c|c|}
\hline & B & Std. Error & $t$ & Sig. \\
\hline \multicolumn{5}{|c|}{ Model 1 (Demographic) } \\
\hline Constant & 1.665 & 0.027 & 60.864 & 0.000 \\
\hline Gender (1=Male) & 0.598 & 0.015 & 39.147 & 0.000 \\
\hline Age & 0.014 & 0.001 & 26.531 & 0.000 \\
\hline African-American (1=Afr. Amer.) & -0.444 & 0.026 & -17.273 & 0.000 \\
\hline Hispanic (1=Hisp.) & -0.223 & 0.028 & -7.966 & 0.000 \\
\hline Asian $(1=$ Asian $)$ & -0.187 & 0.042 & -4.425 & 0.000 \\
\hline Other ethnicity ( 1 = Other) & 0.006 & 0.047 & 0.136 & 0.892 \\
\hline Income & 6.33E-06 & 0.000 & 34.457 & 0.000 \\
\hline Marital status (1=Married/partnered) & 0.026 & 0.017 & 1.510 & 0.131 \\
\hline Education $(1=$ College or more $)$ & 0.541 & 0.019 & 28.432 & 0.000 \\
\hline \multicolumn{5}{|c|}{ Model 2 (Demographic \& Geographic) } \\
\hline Constant & 1.701 & 0.064 & 26.466 & 0.000 \\
\hline Gender & 0.595 & 0.015 & 39.028 & 0.000 \\
\hline Age & 0.014 & 0.001 & 26.658 & 0.000 \\
\hline African-American & -0.414 & 0.027 & -15.237 & 0.000 \\
\hline Hispanic & -0.225 & 0.030 & -7.578 & 0.000 \\
\hline Asian & -0.182 & 0.045 & -4.060 & 0.000 \\
\hline Other ethnicity & -0.021 & 0.048 & -0.446 & 0.655 \\
\hline Income & $6.45 \mathrm{E}-06$ & 0.000 & 34.513 & 0.000 \\
\hline Marital status & 0.016 & 0.017 & 0.925 & 0.355 \\
\hline Education & 0.541 & 0.019 & 28.340 & 0.000 \\
\hline Alabama & -0.028 & 0.080 & -0.353 & 0.724 \\
\hline Alaska & 0.058 & 0.086 & 0.680 & 0.496 \\
\hline Arizona & 0.013 & 0.080 & 0.168 & 0.866 \\
\hline Arkansas & -0.106 & 0.079 & -1.342 & 0.180 \\
\hline California & -0.021 & 0.081 & -0.261 & 0.794 \\
\hline Colorado & -0.005 & 0.080 & -0.059 & 0.953 \\
\hline Connecticut & -0.199 & 0.080 & -2.496 & 0.013 \\
\hline Delaware & -0.060 & 0.080 & -0.753 & 0.452 \\
\hline District of Columbia & -0.094 & 0.087 & -1.086 & 0.277 \\
\hline Florida & -0.005 & 0.080 & -0.060 & 0.952 \\
\hline Georgia & -0.044 & 0.080 & -0.553 & 0.580 \\
\hline Hawaii & -0.006 & 0.090 & -0.065 & 0.948 \\
\hline Idaho & 0.130 & 0.079 & 1.637 & 0.102 \\
\hline Illinois & -0.098 & 0.080 & -1.229 & 0.219 \\
\hline Indiana & -0.110 & 0.079 & -1.384 & 0.166 \\
\hline Iowa & -0.043 & 0.080 & -0.532 & 0.595 \\
\hline Kansas & -0.110 & 0.079 & -1.385 & 0.166 \\
\hline Kentucky & -0.159 & 0.080 & -1.993 & 0.046 \\
\hline Louisiana & -0.157 & 0.079 & -1.982 & 0.047 \\
\hline Maine & -0.052 & 0.079 & -0.662 & 0.508 \\
\hline Maryland & -0.097 & 0.080 & -1.203 & 0.229 \\
\hline Massachusetts & -0.115 & 0.080 & -1.447 & 0.148 \\
\hline Michigan & 0.049 & 0.079 & 0.619 & 0.536 \\
\hline Minnesota & 0.101 & 0.080 & 1.267 & 0.205 \\
\hline Mississippi & -0.002 & 0.080 & -0.023 & 0.981 \\
\hline Missouri & 0.007 & 0.080 & 0.087 & 0.931 \\
\hline Nebraska & 0.055 & 0.080 & 0.685 & 0.493 \\
\hline Nevada & -0.009 & 0.079 & -0.110 & 0.913 \\
\hline New Hampshire & 0.071 & 0.079 & 0.900 & 0.368 \\
\hline New Jersey & -0.200 & 0.079 & -2.517 & 0.012 \\
\hline New Mexico & 0.013 & 0.080 & 0.162 & 0.871 \\
\hline New York & -0.204 & 0.080 & -2.556 & 0.011 \\
\hline North Carolina & -0.132 & 0.080 & -1.659 & 0.097 \\
\hline North Dakota & 0.007 & 0.085 & 0.080 & 0.936 \\
\hline Ohio & -0.115 & 0.080 & -1.439 & 0.150 \\
\hline Oklahoma & -0.043 & 0.079 & -0.539 & 0.590 \\
\hline Oregon & -0.087 & 0.080 & -1.095 & 0.273 \\
\hline Pennsylvania & -0.206 & 0.079 & -2.600 & 0.009 \\
\hline Rhode Island & -0.071 & 0.079 & -0.894 & 0.371 \\
\hline South Carolina & 0.079 & 0.079 & 1.001 & 0.317 \\
\hline South Dakota & 0.216 & 0.084 & 2.567 & 0.010 \\
\hline Tennessee & -0.147 & 0.080 & -1.834 & 0.067 \\
\hline Texas & -0.001 & 0.081 & -0.007 & 0.994 \\
\hline Utah & 0.089 & 0.078 & 1.139 & 0.255 \\
\hline Vermont & 0.027 & 0.083 & 0.328 & 0.743 \\
\hline Virginia & -0.148 & 0.080 & -1.840 & 0.066 \\
\hline Washington & 0.010 & 0.080 & 0.130 & 0.896 \\
\hline West Virginia & -0.168 & 0.079 & -2.123 & 0.034 \\
\hline Wisconsin & 0.039 & 0.080 & 0.481 & 0.631 \\
\hline Wyoming & -0.035 & 0.085 & -0.407 & 0.684 \\
\hline
\end{tabular}

